\title{
IŠMANIOJI GALIA - RUSŲ KALBOS NAUDOJIMAS, STIPRINANT RUSIJOS FEDERACIJOS GALIA
}

\author{
Mjr. Stasys Vilkinas \\ Generolo Jono Žemaičio Lietuvos karo akademija
}

\begin{abstract}
Anotacija. Rusu kalba yra slavišku kalbu šeimos narè, kuria kalba apie 260 milijonu žmoniu, iš kuriu 150 milijonu ji yra gimtoji kalba. Rusu kalba yra viena populiariausiu kalbu dešimtuke, tačiau naudojama kalbai nebüdingose sferose. Šiame straipsnyje apžvelgiama galiu teorija, kad būtu matoma, kokiq vieta joje užima kalba, ir atskleidžiama, kaip Rusijos Federacija (toliau - RF) taiko kalba savo puolamuosiuose veiksmuose prieš savo kaimynines valstybes. Kremlius naudoja rusu kalba informaciniame kare posovietineje ir slaviškai kalbančiu šaliu erdvèje. Straipsnyje atskleidžiama tik nedidelè dalis istoriniu pavyzdžiu - RF naudojo rusu kalba užtikrinti politiniu, ekonominiu ar kariniu tikslu igyvendinima. Kalba, būdama tik viena iš švelniosios galios resursu, yra išmaniai naudojama stiprinant griežtosios galios resursus. Siekiant laiku apsisaugoti nuo mums neiprasto kalbos panaudojimo, būtina daugiau dèmesio skirti galios teorijos supratimui. Straipsnyje siūloma daugiau dèmesio skirti priežastims, kodèl yra taikoma ši kalba, ir atidžiai vertinti indikatorius, kad būtu laiku užkirstas kelias agresijai ar nacionaliniam saugumui.
\end{abstract}

Pagrindiniai žodžiai: rusų kalba, galia, posovietinè erdve, Rusijos Federacija, agresija.

Ivadas.

Tyrimo objektas - rusų kalba ir jos panaudojimas, stiprinant RF galią.

Tyrimo tikslas - atskleisti, kaip RF valdantis elitas pasitelkia rusų kalbą, kad sustiprintų nacionalinę galią.

\section{Tyrimo uždaviniai:}

1. Parodyti kalbos vietą galios teorijose.

2. Apžvelgti išmaniosios galios strategijos taikymo pagrindus.

3. Atskleisti rusų kalbos vietas RF norminiuose diskursuose.

4. Pasidalinti rusų kalbos taikymo pavyzdžiais posovietinėje erdvėje.

Tyrimo metodai: mokslinès literatūros, norminių dokumentų, internete publikuotos medžiagos ir periodinès spaudos analizès, asmeninès patirties apibendrinimas, atskirų ryškesnių istorinių faktų apžvalga.

Rusų kalba yra slaviškų kalbų šeimos narè, kuria kalba apie 260 milijonų 
žmonių, iš kurių 150 milijonų ji yra gimtoji kalba. Ši kalba oficialiai pripažinta valstybine kalba tokiose šalyse kaip RF, Baltarusijos Respublika, Kazachstanas ir Kirgistanas, o dažnai taikoma ar naudojama kaip mažumų kalba tokiose šalyse kaip Tadžikistanas, Moldovos Respublika, Rumunija, Suomija, Norvegija, Armėnija, Lenkijos Respublika, Čekijos Respublika, Slovakija, Turkmėnistanas ir Uzbekistanas. Pagrindine kalba ji tapo okupuotuose ar RF remiamuose regionuose - Transnistrijoje (Moldovos regionas), Pietų Osetijoje ir Abchazijoje (Gruzijos regionai), Kryme, Donecke ir Luhanske (Ukrainos teritorijos).

Šiame straipsnyje atskleidžiama, kaip RF, būdama didžiausia rusų kalbos naudotoja, taiko ją savo puolamuosiuose veiksmuose prieš savo valstybes ,artimajame užsienyje ${ }^{1 “}$. RF valdantis elitas naudoja šią kalbą - Rusų kultūros sudètinę dalị ir vieną iš švelniosios galios resursų - informaciniame kare posovietineje erdvejje $^{2}$. Didelè dalis posovietinių šalių piliečių Rusiją laiko pagrindine grèsme jų šalies nacionaliniam saugumui, o kartais ir valstybingumui. RF, būdama didžiausia (pagal teritoriją) pasaulio valstybe, yra ypatingai svarbi tarptautinès politikos veikèja regione, o dažnai ir pasaulyje. Jos užsienio ir saugumo politikos klausimai neapsiriboja santykiais su didžiosiomis pasaulio valstybėmis, t. y. Jungtinėmis Amerikos Valstijomis (JAV), Kinija ir tarptautinemis organizacijomis - Jungtinemis Tautomis (JT), Šiaurès Atlanto sutarties organizacija (angl. North Atlantic Treaty Organization - NATO) ar Europos Sajunga (ES). Rusijos elgesys su posovietinemis valstybėmis (Baltarusija, Estija, Gruzija, Latvija, Lietuva ir Ukraina) ${ }^{3}$ dažnai esti arogantiškas - kaip su nepaklūstančiomis savo provincijomis. Dẻl pastarujų Kremliaus sprendimų pasaulyje didèja karo grèsmè - posovietinès valstybės vis dažniau ịvardija vykdomą informacinị karą, kurị pradejjo RF.

\section{Kalbos vieta galios teorijose.}

Analizuojant kalbos vietą galios teorijose, būtina aptarti pačią švelniosios galios sąvoką, kuri plètojama (neo)liberalų paradigmoje. Pasak J. S. Nye, galia sudaro ne tik grasinimui ar atlygiui skirtos priemonès, bet ir veikèjo ideologinis bei kultūrinis patrauklumas". Griežtoji galia yra asocijuojama su „lazdos” arba „morkos" metodais, o švelniosios galios pagalba veikejjas pritraukia kitus sekti kartu, nes sugeba sužavėti savo gyvenimu, vertybėmis, veiklos pavyzdžiais, atvirumu, kultūra: A savo pavyzdžiu sudomina B gyventi pagal A. Nors valstybei yra sunku kontroliuoti savo švelniosios galios kūrima, tačiau galima išskirti tris pagrindinius šios galios komponentus (išteklius): valstybès kultūra (kalba yra vienas iš šio

1 Дугин, А. Г. Основы Геополитики, Москва: Арктогея, http://grachev62.narod.ru/dugin/ chapt06.htm, 2011-02-20.

2 Posovietinè erdvè apima iš Sovietų Sajungos išsivadavusias buvusias sovietines respublikas. Šiame straipsnyje apsiribojama tik europinių respublikų analize.

3 Rusija Sovietų Sajungoje buvusias valstybes ịvardija kaip artimojo užsienio šalis.

4 Berenskoeetter, F., Williams, M. J. (2007). Galia pasaulio politikoje. Power in World Politics. London and New York: Routledge, p. 100-102. 
komponento resursų), politines vertybes (viduje ir užsienyje) ir valstybės vykdomą politiką (angl. policy) (paremtą îstatymais ir turinčią moraliai veikiančią valdžią)

Valstybèse kultūra sudaro vertybès ir ipročiai, sudarantys prasmę visuomenei. [...] Yra priimtina atskirti aukštaja (angl. high) kultūra kaip literatūra, menas ir mokslas, kas priskiriama elitui пио populiariosios kultūros, kuri apima masine pramoginę kultüra (angl. entertainment) ${ }^{6}$.

Pasak J. S. Nye ${ }^{7}$, griežtoji ir švelnioji galios gali paveikti objektus savo naudai. Švelnioji galia yra sena demokratinių valstybių vidaus politikos realija. Skirtumas tarp šių galių yra tik veikejjo elgsenoje - ar jis naudoja galias priversti objektą ịsakinëjant, ekonominėmis priemonėmis ar tiesiog įtikinant patrauklumu. Tai geriausiai atskleidžiama pirmojoje lentelèje.

1 lentelè. Trys galios (J. S. Nye ${ }^{8}$ )

\begin{tabular}{|c|c|c|c|}
\hline & ELGSENA & $\begin{array}{l}\text { PAGRINDINĖS } \\
\text { SAVYBĖS }\end{array}$ & VALSTYBĖS POLITIKA \\
\hline $\begin{array}{l}\text { KARINE் } \\
\text { GALIA }\end{array}$ & $\begin{array}{l}\text { Prievarta } \\
\text { Atgrasymas } \\
\text { Apsauga }\end{array}$ & $\begin{array}{c}\text { Grèsmès } \\
\text { Pajègumai }\end{array}$ & $\begin{array}{c}\text { Prievartinė diplomatija } \\
\text { Karas } \\
\text { Sajungos }\end{array}$ \\
\hline $\begin{array}{l}\text { EKONOMINE } \\
\text { GALIA }\end{array}$ & $\begin{array}{c}\text { Paskatinimas } \\
\text { Prievarta }\end{array}$ & $\begin{array}{l}\text { Mokesčiai } \\
\text { Sankcijos }\end{array}$ & $\begin{array}{c}\text { Pagalba } \\
\text { Papirkimas } \\
\text { Sankcijos }\end{array}$ \\
\hline $\begin{array}{l}\text { ŠVELNIOJI } \\
\text { GALIA }\end{array}$ & $\begin{array}{l}\text { Sužavėjimas } \\
\text { Darbotvarkès } \\
\text { sudarymas }\end{array}$ & $\begin{array}{c}\text { Vertybès } \\
\text { Kultūra (kalba) } \\
\text { Politika } \\
\text { Institucijos }\end{array}$ & $\begin{array}{l}\text { Viešoji diplomatija } \\
\text { Dvišalè ir daugiašalè diplomatija }\end{array}$ \\
\hline
\end{tabular}

Anot J. S. Nye, valstybių politikai ar valstybę valdančios politinès grupės, siekdami norimos paramos, gali naudoti prievartą arba materialini skatinimą, tačiau svarbų vaidmenį, užsitikrinant paramą visuomenèje, vaidina patrauklumas. Būtent partauklumo savybe pasižymi kalba. Tai atsispindi pateikiamoje antrojoje lenteleje, kurią sudarẻ J. S. Nye:

5 Nye, S. J. (2010). Public Diplomacy and Soft Power, SAGE Journal online, http://ann.sagepub. com/content/616/1/ 94.abstract, 2010-12-23.

6 Nye, J. S. (2004). Švelnioji galia: priemonè pasiekti sèkmę pasaulinėje politikoje. Soft Power:

The Means to Success in World Politics, New York: Public Affairs, p. 11-15.

7 Ten pat, p. 7.

8 Ten pat, p. 31. 
2 lentelè. Galia pagal J. S. Nye ${ }^{9}$

\begin{tabular}{|c|c|c|c|c|c|}
\hline & \multicolumn{3}{|c|}{ GRIEŽTOJI GALIA } & \multicolumn{2}{|r|}{ ŠVELNIOJI GALIA } \\
\hline ELGESIO & & & $\begin{array}{c}\text { Materialiniai } \\
\text { skatinimai }\end{array}$ & $\begin{array}{c}\text { Darbotvarkès } \\
\text { diktavimas }\end{array}$ & $\begin{array}{l}\text { Patraukimas } \\
i \text { savo pusę }\end{array}$ \\
\hline SPEKTRAS & $\begin{array}{l}\text { Isakiniëjimas } \\
\text { (angl. command) }\end{array}$ & $\leftarrow 0$ & $-\mathrm{O}$ & - & $-\mathrm{O} \longrightarrow$ \\
\hline $\begin{array}{l}\text { TIKE்TINI } \\
\text { RESURSAI }\end{array}$ & & $\begin{array}{l}\text { Fizinè jejga } \\
\text { Sankcijos }\end{array}$ & $\begin{array}{l}\text { Atlygis } \\
\text { Papirkimas }\end{array}$ & Institucijos & $\begin{array}{l}\text { Vertybeis } \\
\text { Kultura (kalba) } \\
\text { Elgesys / politikos } \\
\text { kursas }\end{array}$ \\
\hline
\end{tabular}

\section{Išmaniosios galios strategijos taikymo pagrindai}

Siekiant atskleisti švelniosios galios taikymą, stiprinant griežtosios galios priemones vienam tikslui pasiekti ir atvirkščiai, būtina paliesti ir išmaniosios galios sąvoką. Galios taikymas pagal išmaniosios galios strategiją yra sąlyginai naujas ir toks modelis pradètas naudoti tik dvidešimtojo amžiaus pabaigoje. Šios sąvokos autorius, jau minetasis J. S. Nye, 1990 metais savo knygoje Bound to Lead: The Changing Nature of American Power pasiūlè apjungti griežtosios ir švelniosios galiu priemones, vadovaujantis išmaniosios galios teorija, kuri dar kitaip vadinama winning strategy (liet. laiminčia strategija) ${ }^{10}$. Pasak jo, išmaniosios galios strategija formuojama, apjungiant A valstybeje turimus diplomatinius, ekonominius, politinius, karinius, kultūrinius bei teisinius komponentų resursus ir pajegumus su tikslu daryti ịtaką B valstybei (objektui) taip, kad būtų rentabilu (angl. cost-effective) ir politiškai bei socialiai teisèta.

Pasaulyje didejjančios asimetrinès, terorizmo ar masinio naikinimo grèsmès paskatino ieškoti būdų, kaip kovoti su naujais saugumo iššūkiais. Senoji strategija, kai atskirai buvo naudojamos švelniosios arba griežtosios galių priemonès, nepasiteisino kovojant su naujais saugumo iššñkiais. Išanalizavus literatūrą ir pastaraisiais dešimtmečiais vykusius karus bei konfliktus pasaulyje, galima sutikti su Harvardo universiteto profesoriumi J. S. Ney, kad griežtosios galios priemonės nesugebėjo kovoti su grèsmėmis, kurios remiasi didejjančiais žmoniškaisiais resursais, o švelniosios galios priemonès buvo vertinamos kaip silpnumo apraiška. Išmaniosios galios teorijos principais pagrịsta užsienio politika leidžia valstybès valdančiajam elitui ${ }^{11}$ norimu momentu pasitelkti švelniosios ar griežtosios galių reikiamus resursus

\footnotetext{
9 Nye (išnaša 6), p. 8.

10 Nye, J. S. (1990). Priversta vadovauti: besikeičianti Amerikos galios prigimtis. Bound to Lead:

The Changing Nature of American Power, New York: Basic Books.

11 Valdantis elitas - valstybès valdančioji mažuma, kuri turi teisę priimti monopolinius politinius sprendimus.
} 
ir pajègumus ${ }^{12}$, norint pasiekti užsienio ir saugumo politikos tikslus. Išmaniosios galios strategijai taikyti būtini kintamieji - žvalgyba ir informacijos technologijos. Anot J. S. Nye ${ }^{13}$, žvalgyba leidžia teisingai pasirinkti švelniosios ar griežtosios galių priemones, apjungiant jas ị vieningą strategiją, o pasinaudojant informacinėmis technologijomis, galima manipuliuoti pateikiama informacija norimai aplinkai.

Pasitelkus J. S. Nye siūlomą išmaniosios galios formavimo strategijos teoriją, A valstybès griežtosios galios priemonès gali būti panaudojamos, formuojant A valstybès švelniają galią ${ }^{14}$, norint pasiekti išmaniosios galios efektą B valstybei.

Siūlomi B. Buzano galios formavimo tikslai - galios varžybos ir saugumo varžybos - leidžia suskirstyti ir atskleisti priežastis, kodẻl Kremlius taiko skirtingas galios formas santykiuose su kaimynėmis. Valstybių skirstymas ị hegemonus, hegemonų klientus ir vasalus leidžia skirstyti posovietinès erdvės valstybes, vertinant jų santykius su Rusija. Tiriant RF santykius su europinėje dalyje esančiomis posovietinès erdvès valstybėmis, yra pastebima, kaip, siekiant užtikrinti sẻkmingą užsienio ir saugumo politiką, pasitelkiamos karinès, ekonominès, politinès, diplomatinès, simbolinès ir kultūrinès priemonès.

Siekiant analizės aiškumo, nuoseklumo ir konkretumo, buvo sudaryta galių lentelè.

12 Clinton, H. (2011). Use "Smart Power" in Diplomacy, CBS News, http://www.cbsnews.com/ stories/2009/01/13/politics/ main4718044.shtml, 2011-02-25.

13 Nye, J. S. (2009). Get Smart, Foreign Affairs 88 (4), p. 160-163.

14 Nye (išnaša 6), p. 18-21. 
3 lentelè. Galios lentelè (sudaryta autoriaus)

\begin{tabular}{|c|c|c|c|c|c|}
\hline & & PRIEMONĖS & ELGSENA & $\begin{array}{l}\text { PAGRINDINĖS } \\
\text { SAVYBĖS }\end{array}$ & $\begin{array}{c}\text { VALSTYBE்S } \\
\text { POLITIKA }\end{array}$ \\
\hline \multirow{3}{*}{$\begin{array}{l}\text { GRIEŽTOJI } \\
\text { GALIA }\end{array}$} & \multirow{6}{*}{$\begin{array}{l}\text { IŠMANIOJI } \\
\text { GALIA }\end{array}$} & Karinès & $\begin{array}{c}\text { Prievarta } \\
\text { Atgrasymas } \\
\text { Apsauga }\end{array}$ & $\begin{array}{l}\text { Grèsmès } \\
\text { Pajègumai }\end{array}$ & $\begin{array}{l}\text { Prievartinè } \\
\text { diplomatija } \\
\text { Karas } \\
\text { Sajungos }\end{array}$ \\
\hline & & Ekonominès & $\begin{array}{c}\text { Paskatinimas } \\
\text { Prievarta }\end{array}$ & $\begin{array}{l}\text { Mokesčiai } \\
\text { Sankcijos }\end{array}$ & $\begin{array}{c}\text { Pagalba } \\
\text { Papirkimas } \\
\text { Sankcijos }\end{array}$ \\
\hline & & Politinès & Prievarta & $\begin{array}{l}\text { Pajègumai } \\
\text { Grėsmès } \\
\text { Sankcijos }\end{array}$ & $\begin{array}{c}\text { Prievartinė } \\
\text { diplomatija } \\
\text { Politinès } \\
\text { sajungos } \\
\text { Sankcijos } \\
\text { Diplomatinis } \\
\text { susitarimų } \\
\text { vilkinimas }\end{array}$ \\
\hline \multirow{3}{*}{$\begin{array}{l}\text { ŠVELNIOJI } \\
\text { GALIA }\end{array}$} & & Diplomatinès & $\begin{array}{c}\text { Darbotvarkès } \\
\text { sudarymas }\end{array}$ & $\begin{array}{c}\text { Politika } \\
\text { Institucijos }\end{array}$ & $\begin{array}{c}\text { Viešoji } \\
\text { diplomatija } \\
\text { Dvišalè ir } \\
\text { daugiašale } \\
\text { diplomatija }\end{array}$ \\
\hline & & Informacinès & $\begin{array}{c}\text { Prievarta } \\
\text { Sužavèjimas }\end{array}$ & $\begin{array}{c}\text { Politika } \\
\text { Vertybès } \\
\text { Kultūra (kalba) }\end{array}$ & $\begin{array}{c}\text { Informacinis } \\
\text { karas } \\
\text { Viešoji } \\
\text { diplomatija }\end{array}$ \\
\hline & & Simbolinès & Sužavèjimas & $\begin{array}{c}\text { Valstybès } \\
\text { vykdoma politika } \\
\text { Vertybės } \\
\text { Kultūra (kalba) } \\
\text { Ekologija } \\
\text { Technologinio } \\
\text { pasiekimo lygis } \\
\text { Dvasinis pasaulis } \\
\text { ir religija }\end{array}$ & $\begin{array}{c}\text { Viešoji } \\
\text { diplomatija }\end{array}$ \\
\hline & \multicolumn{5}{|c|}{ Žvalgyba } \\
\hline & \multicolumn{5}{|c|}{ Informacijos technologijos } \\
\hline
\end{tabular}




\section{Galios samprata Rusijos oficialiame politiniame diskurse}

Tiriant RF vystymosi raidą po Sovietų Sajungos žlugimo, galima pastebèti kelis galios naudojimo etapus, kurie yra sietini su Rusiją valdančiu tuometiniu elitu. Boriso Jelcino ${ }^{15}$ valdymo periodu užsienio ir saugumo politikoje vyravo švelniosios galios priemonès. Atejus ị valdžią Vladimirui Putinui ${ }^{16}$, užsienio ir saugumo politika pasikeite - švelniosios galios priemonès liko taikomos tik senojoje Europoje, o artimajame užsienyje pradètos dažniau taikyti griežtosios galios priemonès. Panašią politiką vykdè ir Dmitrijus Medvedevas ${ }^{17}$. Laikotarpis, kai 1999 metais atsistatydino B. Jelcinas ir ị vadžią atejo V. Putinas, gali suteikti galimybę ịvesti ir dar vieną periodą, kai RF valdantis elitas pradejjo taikyti griežtosios galios priemones be švelniosios galios tolimajame užsienyje. V. Putinas ir D. Medvedevas siekia atkurti Sovietų Sajungos arba Carinès Rusijos turètą galią ir politinę įtaką pasaulyje. Tai atsispindi oficialiame politiniame diskurse.

Rusija, pagrịsdama ir igyvendindama užsienio ir saugumo politiką bei augindama nacionalinę galią, vadovaujasi šiais dokumentais: Rusijos Federacijos užsienio politikos koncepcija (2008 m. liepos $15 \mathrm{~d}$. patvirtintas papildymas $2000 \mathrm{~m}$. birželio 28 d. patvirtintai koncepcijai) (toliau - koncepcija) ${ }^{18}$, Rusijos Federacijos nacionaline saugumo strategija iki 2020 metu $^{19}$ (dokumentas patvirtintas $2009 \mathrm{~m}$. gegužès 12 d.) (toliau - strategija), Rusijos Federacijos karine doktrina ${ }^{20}$ (nuo $2014 \mathrm{~m}$. gruodžio $26 \mathrm{~d}$. galioja doktrina, kuri pakeite $2010 \mathrm{~m}$. vasario $5 \mathrm{~d}$. doktriną, kuri pakeite $2000 \mathrm{~m}$. balandžio $21 \mathrm{~d}$. doktriną, kuri pakeitè $1993 \mathrm{~m}$. lapkričio 2 d. karinę doktriną) (toliau - karinè doktrina), Rusijos Federacijos informacinio saugumo doktrina ${ }^{21}$ (galioja nuo $2016 \mathrm{~m}$. gruodžio $5 \mathrm{~d}$., kuri pakeite $2000 \mathrm{~m}$. rugsèjo 9 d. doktriną) (toliau - informacinè doktrina). Išanalizavus šiuos dokumentus, galima teigti, kad RF karinę galią formuoja vadovaudamasi visais išvardintais dokumentais.

15 Borisas Jelcinas - RF prezidentas 1991-1999 metais.

16 Vladimiras Vladimirovičius Putinas ejo Prezidento pareigas nuo 1999 iki rinkimų 2000 metais, RF Prezidentas 2000-2008 metais ir nuo 2012 metų.

17 Dmitrijus Medvedevas - RF Prezidentas 2008-2012 metais.

18 Концепциия внешней политики Российской Федерации, Совет Безопасности Российской Федерации, http://www.scrf.gov.ru/documents/2/25.html, 2011-03-20; Концепция внешней политики Российской Федераџии, Kremlin, http://www.kremlin.ru/acts/785, 2011-03-20.

19 Стратегия национальной безопасности Российской Федерации до 2020 года национальной безопасности Российской Федерации до 2020 года, Совет Безопасности Российской Федерации, http://www.scrf.gov.ru/documents/1/99.html, 2011-03-20.

20 Военная доктрина Российской Федерации, Consultant, http://base.consultant.ru/cons/cgi/ online.cgi?req= doc;base=EXP;n=217483, 2011-03-20 Военная доктрина Российской Федерации, Совет Безопасности Российской Федерации, http://www.scrf.gov.ru/documents/18/33.html, 2011-03-20.

21 Доктрина информационной безопасности Российской Федерации, Совет Безопасности Российской Федерации, http://www.scrf.gov.ru/documents/6/5.html, 2011-03-20; Доктрина информационной безопасности Российской Федераиии, Российская газета, https://rg.ru/2016/12/06/doktrina-infobezobasnost-site-dok.html, 2016-12-20. 


\section{Rusijos Federacijos užsienio politikos koncepcija.}

Rusijos Federacijos užsienio politikos koncepcija (toliau - koncepcija) tik bendrais bruožais pristato pagrindinius Rusijos užsienio politikos prioritetus. Išanalizavus šį dokumentą, prognozuojama, kad Rusija sieks aktyviau realizuoti eurazijinès ašies ideją̨ ${ }^{22}$, pagal kurią ji taptų jungiamaja grandimi tarp Europos ir Rytų. Joje tiesiogiai galime rasti vietą rusų kalbos panaudojimui.

Dokumente yra ịvardijami politinio, ekonominio, intelektualinio ir dvasinio potencialo stiprinimo klausimai, kurie sietini su politinių, ekonominių ir simbolinių galių priemonių pajègumais. Išsamiau analizuojant dokumentą, galima teigti, kad Rusija, vykdydama savo užsienio ir saugumo politiką, linkusi taikyti griežtąją galią, stiprinant ją švelniaja galia ar net taikant išmaniajją strategiją. Būtent 2008 metų koncepcijoje akivaizdžiai minima švelnioji galia. Šios galios priemonių resursai ir pajègumai: rusų kalba, istorinės vertybè ${ }^{23}$ ir Rusijoje gyvenančių tautybių kultūros populiarinimas yra sietini su simboline galia ${ }^{24}$ ir yra plačiai naudojami, vykdant viešają diplomatiją bei informacinio karo atskirus veiksmus. „, ,..> skatinti teigiamą požiūrị i Rusijos Federaciją pasaulyje, rusų kalbos ir Rusijos tautų kultūros populiarinimas užsienio šalyse.“25

Koncepcijoje didžioji dalis posovietinèje erdvèje esančių šalių išlieka Rusijos interesų zonoje, siekiant sustiprinti Rusijos galią. Didžiausias dèmesys čia skiriamas Nepriklausomų valstybių sandraugos (toliau - NVS) erdvei (čia rusų kalba yra naudojama politikoje, ekonomikoje, kultūroje ir kituose bendradarbiavimo formatuose). Bendrame kontekste galima suprasti, kad tai neaplenkia tokių valstybiu kaip Estija, Gruzija, Latvija, Lietuva ir Ukraina. Tiriant šiuolaikinius Kremliaus veiksmus ir atsižvelgiant ị 2008 metų koncepciją, galima daryti išvadą, kad Rusija didina savo galią, nekreipdama dẻmesio ị posovietinių valstybių teises.

\section{Rusijos Federacijos nacionalinė saugumo strategija iki 2020 metų.}

Rusijos Federacijos nacionalinė saugumo strategija iki 2020 metu yra sisteminis strateginių politikos prioritetų, tikslų ir priemonių dokumentas. Šis dokumentas aiškiau negu Rusijos Federacijos užsienio politikos koncepcija atskleidžia galimus Rusijos užsienio ir saugumo veiksmus bei galios priemonių panaudojimą santykiuose su kitomis valstybėmis.

22 Дугин, А. Г. (2004). Проект „Евразия“, Москва: ЭКСМО, Яуза.

23 Dokumente akcentuojama būtinybė išsaugoti nepakitusị Antrojo pasaulinio karo ir po jo ejusio istorinio periodo traktavimą.

24 Bourdieu, P. (1991). Language and Symbolic Power, Cambridge, Massachusetts: Harvard University Press.

25 Išnaša 14. 
Apžvelgus pirmają dokumento dalị, galima daryti išvadą, kad Rusijos nacionaliniai interesai ${ }^{26}$ yra už jos teritorijos ribų ir siekia buvusią Varšuvos sutarties organizacijos ${ }^{27}$ erdvę bei slavų kalbą vartojančias šalis. Spejjama, kad Rusijos posovietinèje erdveje elitas yra labiau linkęs naudoti griežtają galią nei santykiuose su Centrinès ir Vakarų Europos ar Azijos valstybėmis. Remiantis šiuo dokumentu, matyti, kad pagrindinès Rusijos grèsmès kyla iš Šiaurès Atlanto sutarties organizacijos (toliau - NATO) (o tiksliau - NATO plètros ir posovietinejje erdvejje esančiu valstybių elito, siekiančio įstoti į ši aljansą) ir Vakarų pasaulio vykdomos užsienio politikos.

Rusijos Federacijos nacionalinėje saugumo strategijoje iki 2020 metų keliami keli tikslai, kuriant Rusijos galią, tačiau vienas iš jų gali būti sietinas ir su rusų kalbos panaudojimu:

Stiprinti organizacijas (NVS, Kolektyvinio saugumo sutarties organizacijas (angl. Collective Security Treaty Organization) (toliau - KSSO), Europos-Azijos ekonomines bendrijas (angl. Eurasian Economic Community) (toliau - EAEB) ir t. t.), kuriose Rusija turi didelę įtaką (šiose organizacijose yra plačiai naudojama rusų kalba) tam, kad padidintų savo politinę galią.

Siekiant užtikrinti Rusijos saugumo politikos tikslus, dokumente, pirmiausia, minimi tokie galios kintamieji kaip gyventojai (gyventojų skaičiaus didinimas, gyvenimo sąlygų gerinimas), gerbūvis (mokslinio ir technologinio potencialo stiprinimas, išsilavinimo sąlygų bei ekologinès situacijos gerinimas, sveikatos lygio pakèlimas) ir vertybès (kultūra ir kalba). Vadovaujantis J. S. Nye, šie kintamieji yra pagrindas valstybėse, formuojant švelniąją galią. Toliau dokumente yra minimi ir griežtosios galios kintamieji (valstybę valdantis elitas ar valstybeje vykdoma politika, karinè jèga, gerbūvis (čia turima omenyje valstybès ekonominius išteklius), kurie papildo jau minètų galios resursų ir pajègumų sąrašą.

\section{Rusijos Federacijos informacinio saugumo doktrina.}

Dar vienas minètinas RF politinis diskursas - informacinio saugumo doktrina, patvirtinta $2016 \mathrm{~m}$. gruodžio 5 d. Ji yra Rusijos Federacijos saugumo koncepcijos tęsinys informacinejje srityje. Dokumentas skirtas „formuoti valstybės politiką informacinio saugumo srityje, tobulinti teisinę bazę bei skatinti kurti tikslines programas informacinejje srityje. Minèta doktrina nurodo kryptis bei prioritetus, bet neteikia konkrečių rekomendacijų dèl informacinio saugumo." ${ }^{28}$ Tiriant šį dokumentą, galima taikyti prielaidą, kad, plètojant puolamuosius (prievartą ar sužavè-

\footnotetext{
26 Ten pat.

271955 m. Sovietų Sajungos ịtakoje buvusių komunistinių Europos valstybių pasirašyta karinio aljanso sutartis. $1991 \mathrm{~m}$. sutartis panaikinta. Varšuvos sutarties organizacijos (toliau - VSO) narès buvo SSRS, Lenkija, Čekoslovakija, Vengrija, Rumunija, Bulgarija, Vokietijos Demokratinė Respublika ir Albanija (pasišalino iš Varšuvos sutarties organizacijos 1968 m.).

28 Maliukevičius, N. Informacijos karas: Rusijos požiūris. Post Scriptum, http://www.postscriptum.lt/7-karas/ informacijos-karas-rusijos-poziuris/, 2011-04-06.
} 
jimą) veiksmus, RF naudosis tais pačiais resursais ir metodais, formuojant galią prieš kaimynines respublikas (gali būti pritaikytas ,,veidrodinis efektas“), kaip yra įvardinti kitų valstybių metodai ir resursai, kurie kelia grèsmes ir pavojus Rusijai.

Toliau analizuojant šị dokumentą (2016 m.), išsiskiria trys galios kintamųu apsaugos grupès:

- nacionalinių vertybiu (kuriose kalbama apie kultūrą ir rusų kalbą);

- valstybès politinès sistemos;

- informacinių sistemų ir resursų (praktiniai pavyzdžiai atskleidžia, kad šioje vietoje vèl nemažas dèmesys skiriamas rusų kalbai).

Šiame dokumente nurodomi potencialūs informacinio karo taikiniai (valstybès nacionaliniai interesai), kuriuos reikia apsaugoti ginantis ar atakuoti, vykdant puolamuosius veiksmus. Minimi informacinio karo $^{29}$ taikiniai yra ịvairiose valstybės srityse: ekonomikos, vidaus politikos, užsienio politikos, mokslo ir technikos, kultūros, komunikacijos, karinèje, teisinèje. Nors šie taikiniai nurodomi kaip agresoriaus taikiniai Rusijoje, galima nuspèti, kad Rusija, formuodama savo puolamuosius galios resursus, pati taikysis ị doktrinoje minimus taikinius.

Informacinès ir diplomatinès galių resursuose ir pajègumuose minimos galimybès:

- perduoti Rusijoje sukurtą neiškraipytą informaciją savo piliečiams tiek valstybės viduje, tiek už jos ribų ir užsienio atrinktai auditorijai;

- skleisti informaciją, kuri kovotų su dezinformacija ar neteisinga informacija;

- didinti informacinès erdvès lauką (geografiškai apima ir posovietines valstybes);

- kurti informacinę produkciją (TV programas, CD, DVD, į visuomenę nukreiptas laidas ir t. t.);

- kurti informacinę technologiją, kuri neatsiliktų nuo pasaulinių naujovių.

Tiriant kintamuosius, kurie minimi doktrinoje, išsiskiria švelniają galią formuojančių kintamujų dominavimas. Nors Rusijos Federacijos informacinio saugumo doktrina daugiau kalba apie švelniosios galios priemonių resursus, kurie veiktų taikant išmaniosios galios strategijos pagrindu, gali būti taikomi stiprinant karinę ar politinę galias. Apžvelgiant jau minètas galimybes, galima teigti, kad juose didelị vaidmenį suvaidins rusų kalba. Dokumente neatmetama galimybẻ informacinę galią nukreipti prieš kitas valstybes.

29 Informacinis karas yra bet koks veiksmas paneigti, panaudoti, sugadinti arba sunaikinti priešo informaciją ir jo funkcijas; apsaugoti save nuo tokių pat veiksmų bei išnaudoti turimus karinès informacijos pajègumus. 


\section{Rusų kalbos taikymas posovietinėje erdvèje}

Istoriškai Rusijos valdančiajam elitui buvo būdinga skatinti rusų kalbą ar net drausti okupuotų teritorijų piliečiams naudoti savo kalbą ar vietoje jos versti naudoti rusų. Tai buvo daroma tiek carinėje Rusijoje ${ }^{30}$, tiek Sovietų Sajungos laikais (rusų kalba visose okupuotose respublikose buvo pripažinta valstybine, daug dèmesio jos prievartiniam skatinimui buvo skirta aštuntame ir dešimtame dešimtmetyje) ir jau minètais Putino valdymo periodais. Rusų kalba tapo Rusijos politikos, ekonomikos ir karinès galios dalimi.

Žvelgdami ị vieną iš griežtosios galios priemonių - politinę galią, - galime apžvelgti RF valdančio elito pasisakymus ir valdžios sprendimus, susijusius su rusų kalbos platinimu posovietinejje erdvejje. RF prezidentas V. Putinas 2016 metais vykusiame Rusijos kalbotyros suvažiavime eilinį kartą pareiškė, kad „rusų kalbos, literatūros ir kultūros išsaugojimas - nacionalinio saugumo, identiteto išsaugojimo klausimas pasaulyje“31. Dar 2001 metais jis ragino trijų Baltijos šalių rusakalbius gyventojus reikalauti, kad rusų kalbai būtų suteiktas antros oficialiosios kalbos statusas $^{32}$. Nuo 2001 metų Rusijos tautiečių kongresas ${ }^{33}$ skyrè ženklų finansavimą posovietinių šalių diasporai ${ }^{34} .2003$ metais ši suma siekè 210 milijonų rublių, o 2004 metais ši suma išaugo dar 20 procentų. Siekiant populiarinti rusų kalbą, buvo sukurta valstybinè programa „Rusų kalba“, kuriai tuo metu vadovavo Liudmila Putina (buvusi V. Putino žmona), o dabar - L. Očeretnaja. Programą finansuoja RF. İkurti slaviški universitetai efektyviai populiarina rusų kalbą tokiose šalyse kaip Armėnija, Azerbaidžanas, Kirgistanas ir Tadžikistanas.

Prisimenant ryškesnius pavyzdžius mūsų regione, iškyla 2012 metais vykęs Latvijos referendumas dèl Konstitucijos pataisų. 2011 metais Latvijos Respublikoje prasidèjo didelès diskusijos dèl rusų kalbos naudojimo pas mūsų Šiaurès kaimynus. Jị iniciavo judejimas „Vieninga Latvija“, todèl vèliau Latvija vykdè referendumą dèl Konstitucijos pataisų, o paprastai kalbant - dèl Rusų kalbos taikymo Latvijo-

30 Po 1863-1864 m. sukilimo Rusijos imperijos valdžios įvestas draudimas europinès imperijos dalies gubernijose spausdinti, ịvežti ir platinti lietuviškus (o taip pat ir latvių katalikų) leidinius lotyniškomis raidėmis (buvo reikalaujama naudoti kirilicą). Draudimas galiojo iki 1904 m. Mokymas lietuvių kalba visiškai uždraustas Vilniaus gubernijoje, o Kauno gubernijoje leista naudoti tik kaip pagalbinę kalbą pirmaisiais metais.

31 Кира Латухина, Путин назвал сбережение русского языка вопросом нацбезопасности https://rg.ru/2016/05/26/putin-nazval-sberezhenie-russkogo-iazyka-voprosom-nacbezopasnosti.html, 2016-10-30.

32 Bugajski, J. (2006). Šaltoji taika: naujasis Rusijos imperializmas. Iš anglų kalbos vertè Tamošiūnaitè, I., Turauskienè, R. - Vilnius: Artlora, 2006, ISBN 10:9955-508-19-1. ISBN 13:978-9955508-19-9, p. 128.

33 Rusų tautiečių kongresas - (rusiškai - Конгресс русских общин) Dmitrijaus Ragozino politinè sąjunga, kuri buvo įkurta 1992 metais ir veikè 1993-2003 metais, o atkurta 2011 metais.

34 Gerasymchuk, S., Matiychyk, Y., Nantoi, O. Competition of Geopolitical Interests in PostSoviet Space: Future Prospects for the Eastern Partnership Countries, http://www.academia. edu/7874022/Competition of_Geopolitical_Interests_in_Post-Soviet_Space_Future_Prospects_ for_the_Eastern_Partnership_Countries, 2016-11-06. 
$\mathrm{je}^{35}$. 2011-2012 metų spaudoje mirga daugybė pasisakymų iš įvairių RF valdžios atstovų ir diplomatų, kurie ragino suteikti valstybinị statusą rusų kalbai. Po jiems nepasisekusio referendumo pasipylè gausybè kaltinimų, kad nèra įsiklausoma ị mažumos pageidavimus ir kad mažumos yra skriaudžiamos. Panašaus spaudimo Latvija susilaukè po Švietimo reformos įvykdymo 2004 metais. Šios reformos tikslas buvo sukurti vieningą švietimo programą, dėstomą tik latvių kalba: apjungti rusų ir latvių vykdomas programas. Dèl šio sprendimo mūsų kaimynè buvo kaltinama siekiais diskriminuoti rusakalbius ir atimti rusų kalbą iš jaunosios kartos ${ }^{36}$.

Karinès galios stiprinimo pavyzdžių nereikia ieškoti toli nuo Lietuvos sienų - užtenka prisiminti Baltarusiją $a^{37}$. Čia Rusijos ir Baltarusijos kariuomenių bendradarbiavimas yra vykdomas Rusijos ir Baltarusijos sajungos sutarties remuose. Ne paslaptis, kad Baltarusijos kariuomenejje ir karinèse mokymo institucijose vyrauja rusų kalba. Karinis bendradarbiavimas, procedūros vykdomi ir mokymo literatūra yra parašyta rusų kalba.

Rusų kalba yra oficiali tokiose organizacijose kaip Nepriklausomų valstybių sandrauga (NVS), Eurazijos ekonominè bendrija (EurAzES) ir Kolektyvinio saugumo sutarties organizacija (KSSO). Šiomis organizacijomis Rusija siekia stiprinti savo nacionalinę galią ekonomikoje, politikoje ir net karinejje sferoje. Kaip priešingybė yra Europos Sajunga, kurioje visų narių kalba yra taikoma lygiomis teisėmis, o NATO taiko dvi oficialias kalbas - anglų ir prancūzų.

Prisimindami diplomatinius RF veiksmus ir vykdytą užsienio politiką Baltijos regione, pastebime daugybę pavyzdžių, kai rusų kalba tapo nesutarimų objektu. Visai neseniai, 2016 metų lapkričio 18 dieną, ypatinga Užsienio reikalų ministerijos igaliotinè Eleonora Mitrofarovna eilinį kartą išsakè Kremliaus poziciją dèl rusų kalbos naudojimo iš Sovietų okupacijos išsivadavusiose šalyse ${ }^{38}$. Pasako jos, Rusija turi siekti, kad tokios šalys kaip Latvija, Estija, Ukraina ir Kazachstanas rusų kalbą įtrauktų i nacionalinę Konstituciją. Ji taip pat teigè, kad „Latvijoje ir Estijoje didelè dalis gyventojų kalba rusų kalba, bet teisiniame lygyje tai nèra matoma. Šalyse vykdoma rusų kalbos diskriminacija, pirmiausiai, mokslo srityje. “39

2012 metais tuometinis Ukrainos prezidentas Viktoras Janukovičius, derèdamasis dèl dujų tiekimo, buvo verčiamas taisyti ịstatymus ir ịteisinti rusų kalbą kaip antrą Ukrainos kalbą, tačiau tam priešinosi didesnioji dalis ukrainiečių. Dar 2010 metais jis gavo palaikymą iš Kremliaus dẻl to, kad žadèjo vykdyti Rusijai palankių sprendimų įteisinimą - vienas iš jų ir buvo rusų kalbos klausimas.

\footnotetext{
35 Latvijoje gyvena $26,9 \%$ rusų mažumos.

36 „Главный мотив реформы образования в Латвии - выбить из русской общины иелое поколение“, Известия, 2004-08-29, http://www.izvestia.ru/press/article2587701, 2010-09-10.

$371999 \mathrm{~m}$. Baltarusijos gyventojų statistikos apklausos metu buvo nustatyta, kad 62,8 procento gyventojų namuose bendrauja rusų kalba, kai baltarusių-gudų kalba kalba tik 36,7 procento gyventojų.

${ }_{38}$ МИД России требует „законодательный статус“ для русского языка в „странах бывшего СССР“, http://ru.aravot.am/2016/11/18/226896/, 2016-12-01.

39 Ten pat.
} 
Taip pat norisi paminèti ir kasdienius veiksmus, pavyzdžiui, rusų kalba yra naudojama manipuliuoti mūsų piliečiais ir mūsų šalies draugais. Tai vykdoma taikant informacinès doktrinos principus - propagandos pavyzdžiai. Pastaruoju metu didinamas rusų kalbos patrauklumas ir kartu jis išnaudojamas, skleidžiant „Kremliaus" politiką, strateginę klaidingą informaciją ir melą. Vieną iš pavyzdžių galime pateikti Lietuvos radijo ir televizijos komisijos (toliau - LRTK) sprendimus uždrausti laikinai transliuoti programas Lietuvoje, kuriose buvo skelbiamas melas ir neteisinga informacija ${ }^{40}$.

Čia kalbos patrauklumas yra skatinamas kultūros pagrindu: plačiai transliuojamų rusiškų programų, rusiškų filmų bei muzikos prieinamumu ir kainos konkurencingumu. Žiūrèdami kabelinę televiziją, galime pastebèti, kad vakarietiški filmai yra greičiau išverčiami ị rusų kalbą ir transliuojami per kabelinès televizijos programas posovietinejje erdveje nei ị tų šalių kalbas. Mažesnių nei vakarietiškų kainų ir gausus nemokamos produkcijos platinimas virtualioje erdveje išlaiko ir net didina susidomėjimą išmokti rusų kalbą bei žiūrèti ar klausytis šia kalba siūlomą produkciją. Kartu su šia gausia pasiūla yra skleidžiamas melas ir vykdomi psichologiniai veiksmai, informacinis karas - puolamieji veiksmai Lietuvoje ir kitose posovietinèse ar net slaviškai kalbančiose šalyse ${ }^{41}$. Tai plačiai nušviesta žiniasklaidoje, kalbant apie Rusijos karą su Ukraina.

\section{Išvados}

- Rusų kalba yra svarbi RF formuojamos švelniosios galios sudètinè dalis, kuri geba sudominti, patraukti link savęs didelę dalị posovietinių ir slaviškų šaliu gyventojų. Galime spèti, kad kalbos sukeliami efektai yra gerai išnagrinèti RF valdžios, nes plačiai taikomi, stiprinant kitas šios valstybès galias. „Kremlius“ sumaniai išnaudoja kalbos paplitimą ir patrauklumą, kad būtų pasiektas norimas tikslas. Kad apsaugotų nacionalinius interesus, būtina mokyti piliečius atskirti propagandą nuo kultūros, o valdžios atstovus gebèti laiku reaguoti ị kylančias grèsmes.

- Rusija yra viena iš pasaulio valstybių, kuri demonstruoja gebejjimus išnaudoti savo kalbą tam, kad sustiprintų kitų galios priemonių pajëgumus, ar vykdant puolamuosius veiksmus, kariaudama informacini, nekonvencini ar asimetrini karus. Reikia mokyti saugumo ir gynybos srityse dirbančius specialistus identifikuoti puolamuosius veiksmus, kuriuos Rusija sugeba vykdyti, pasitelkdama švelniosios galios priemones, treniruoti ịvairius atsakus ir išrinkti labiausiai tinkamus mūsų regionui.

\footnotetext{
40 Europos komisija pripažino - LRTK sprendimas proporcingas ir pagrịstas. Lietuvos radijo ir televizijos komisija, http://www.rtk.lt/pranesimai-spaudai/europos-komisija-pripazino-lrtk-sprendimas-proporcingas-ir-pagristas/, 2017-02-03.

41 Informacinis karas su Rusija: raginimai išjungti rusiškus kanalus be dideliu diskusijų. Lietuvos radijas ir televizija, http://www.lrt.lt/naujienos/lietuvoje/2/64471, 2016-02-02.
} 
- Kalba yra naudojama, vykdant užsienio ir vidinę politikas bei yra minima pagrindiniuose RF diskursuose. Valdantis elitas savo kalbose dažnai mini jos svarbą nacionaliniam saugumui. Politinio diskurso studijos leidžia iš anksto pasirengti priešiškiems veiksmams, tik juos reikia laiku ir kokybiškai ịvertinti.

- Dèl rusų kalbos patrauklumo RF valdantis elitas sėkmingai ją taiko, pasinaudodamas populiariąja kultūra, vykdydamas psichologinius ir propagandinius veiksmus. Kad būtų apsaugoti mūsų piliečiai, reikia mokyti juos suprasti ir atsirinkti skleidžiamą propagandą nuo masinès informacijos, skatinti greitesnį užsienietiškos masinės kūrybos vertimą ị lietuvių kalbą, subsidijuoti vertimą ir programų bei filmų kūrimą (įskaitanat rusų kalba), kad būtų padidintas konkurencingumas rusiškai produkcijai.

- Rasti formas, kad būtų atskirta rusakalbių mažuma nuo priešišką veiklą vykdančiujjų, kad nebūtų didinamas atskirimas nuo lietuvių ir joje gyvenančių rusakalbių Lietuvos gyventojų.

\section{Literatūra}

1. Berenskoeetter, F., Williams, M. J. (2007). Power in World Politics. London and New York: Routledge.

2. Bourdieu, P. (1991). Language and Symbolic Power, Cambridge, Massachusetts: Harvard University Press.

3. Bugajski, J. (2006). Šaltoji taika: naujasis Rusijos imperializmas, iš anglu kalbos vertè Tamošiūnaite, I., Turauskienè, R. - Vilnius: Artlora, ISBN 10:9955508-19-1. ISBN 13:978-9955-508-19-9.

4. Clinton, H. Use "Smart Power" in Diplomacy, CBS News, http://www. cbsnews.com/stories/2009/01/13/politics/ main4718044.shtml, 2011-02-25.

5. Дугин, А. Г., Основы Геополитики, Москва: Арктогея, http:// grachev62.narod.ru/dugin/chapt06.htm, 2011-02-20.

6. Дугин, А. Г. (2004). Проект „Евразия“, Москва: ЭКСМО, Яуза.

7. Доктрина информационной безопасности Российской Федерации, Совет Безопасности Российской Федерации, http://www.scrf.gov.ru/ documents/6/5.html, 2011-03-20.

8. Europos komisija pripažino - LRTK sprendimas proporcingas ir pagristas, Lietuvos radijo ir televizijos komisija, http://www.rtk.lt/pranesimai-spaudai/ europos-komisija-pripazino-lrtk-sprendimas-proporcingas-ir-pagristas/, 2017-02-03.

9. Informacinis karas su Rusija: raginimai išjungti rusiškus kanalus be dideliu diskusiju, Lietuvos radijas ir televizija, http://www.lrt.lt/naujienos/lietuvoje/ 2/64471, 2016-02-02.

10. Gerasymchuk, S., Matiychyk, Y., Nantoi, O. Competition of Geopolitical Interests in Post-Soviet Space: Future Prospects for the Eastern Partnership Countries, http://www.academia.edu/7874022/Competition of_Geopolitical Interests_in_Post-Soviet_Space_Future_Prospects_for_the_Eastern_Partnership_ 
Countries, 2016-11-06.

11. Главный мотив реформы образования в Латвии - выбить из русской общины целое поколение, Известия, 2004-08-29, http://www.izvestia.ru/press/ article2587701, 2010-09-10.

12. Кира Латухина, Путин назвал сбережение русского языка вопросом нацбезопасности, https://rg.ru/2016/05/26/putin-nazval-sberezhenie-russkogoiazyka-voprosom-nacbezopasnosti.html, 2016-10-30.

13. Концепция внешней политики Российской Федерации, Совет Безопасности Российской Федерации, http://www.scrf.gov.ru/documents/2/25. html, 2011-03-20; Концепция внешней политики Российской Федерации, Kremlin, http://www.kremlin.ru/acts/785, 2011-03-20.

14. Maliukevičius, N. Informacijos karas: Rusijos požiūris, Post Scriptum, http://www.postscriptum.lt/7-karas/ informacijos-karas-rusijos-poziuris/, 2011-04-06.

15. МИД России требует „законодательньй статус“ для русского языка в „странах бывщего СССР“, http://ru.aravot.am/2016/11/18/226896/, 2016-12-01.

16. Nye, J. S. (1990). Bound to Lead: The Changing Nature of American Power, New York: Basic Books.

17. Nye, J. S. (2009). Get Smart, Foreign Affairs 88 (4).

18. Nye, S. J. Public Diplomacy and Soft Power, SAGE Journal online, http://ann.sagepub.com/content/616/1/ 94.abstract, 2010-12-23.

19. Nye, J. S. (2004). Soft Power: The Means to Success in World Politics, New York: Public Affairs.

20. Стратегия национальной безопасности Российской Федераџии до 2020 года национальной безопасности Российской Федерации до 2020 года, Совет Безопасности Российской Федерации, http://www.scrf.gov.ru/ documents/1/99.html, 2011-03-20.

21. Военная доктрина Российской Федераиии, Consultant, http://base. consultant.ru/cons/cgi/online.cgi?req=doc;base=EXP;n=217483, 2011-03-20; Военная доктрина Российской Федерации, Совет Безопасности Российской Федерации, http://www.scrf.gov.ru/documents/18/33.html, 2011-03-20. 


\title{
SMART POWER: THE USE OF THE RUSSIAN LANGUAGE TOSTRENGTHEN THE POWER OFTHE RUSSIAN FEDERATION
}

\author{
Maj Stasys Vilkinas \\ The General Jonas Žemaitis Military Academy of Lithuania
}

\section{Summary}

The article reveals how the government of the Russian Federation uses the Russian language to strengthen the country's power. Russian is one of the ten most popular languages in the world, yet it is used in the spheres of influence uncharacteristic of languages. Due to the Federation's aggressive actions and its use of the language in the field of hard power, Russian minorities living in the postSoviet areas suffer. Russian-speaking inhabitants are confused about social groups with hostile intentions or offensive actions.

By applying the smart power theory, the paper presents the position of the language in comparison to other power variables and how it can strengthen the resources or variables of hard and soft power. It is revealed how the Russian language is used to strengthen Russian offensive actions. The overview of a few political normative documents important to Russia shows the position the language take in them, directly or indirectly. Finally, the examples of the Russian language use in the last decade are revealed giving a reader better understanding of the way the Russian Federation uses the language to reach military, political and economic goals, uncharacteristic of Lithuania and its allies in the European Union and NATO.

By seeking to retain the worth of the Russian language in the context of other languages, it is necessary to distinguish between the hostile and offensive actions and Russian culture and values that can be learned through the language. To have a timely reaction to aggression requires a timely recognition of its indicators; thus, it is necessary to pay enough attention to teaching our political elite and youth seeking their place in politics. Taking care of the Russian-speaking minorities, more attention and financing must be devoted to the production of media in Russian and the assurance of its quick and high-quality translation into Lithuanian. If possible, it is necessary to create additional channels for the community speaking this language. 


\section{AUTORIAUS LYDRAŠTIS}

Autoriaus vardas, pavardė: Stasys Vilkinas

Mokslo laipsnis ir vardas: politikos mokslų magistras

Darbo vieta ir pareigos: Generolo Jono Žemaičio Lietuvos karo akademija, Studijų skyriaus viršininkas

Autoriaus mokslinių interesų sritys: išmaniosios galios teorijos taikymas, vertinant nacionalines galias - Rusijos Federacijos galios formavimas

Telefonas ir el. pašto adresas: + 3705210 3595; stasys.vilkinas@mil.lt

\section{AUTHOR'S COVER LETTER}

Author's name and surname: Stasys Vilkinas

Academic degree and name: Master of Political Science

Workplace and position: The General Jonas Žemaitis Military Academy of Lithuania, Studies Management Section, Head

Author's research interests: use of smart power theory to build national power, development of powers in the Russian Federation

Telephone and e-mail address: +370 5210 3595; stasys.vilkinas@mil.lt 